\title{
Effects of arginine and lysine addition to casein and soya-bean protein on serum lipids, apolipoproteins, insulin and glucagon in rats*
}

\author{
By M. SUGANO, N. ISHIWAKI, Y. NAGATA AND K. IMAIZUMI \\ Laboratory of Nutrition Chemistry, Kyushu University School of Agriculture, \\ Fukuoka 812, Japan
}

(Received 28 October 1981-Accepted 9 March 1982)

\begin{abstract}
1. The effect of variation in arginine: lysine on the relative cholesterolaemic effects of dietary soya-bean protein and casein was studied. Male rats received semi-purified diets containing soya-bean protein isolate or casein supplemented respectively with varing amounts of lysine or arginine for $40 \mathrm{~d}$ and blood samples were taken after a $5 \mathrm{~h}$ fast.

2. Neither the addition of arginine to casein nor lysine to soya-bean protein modified the intrinsic effect of these proteins on serum cholesterol.

3. Serum triglyceride levels tended to rise with increasing amounts of lysine supplementation. The opposite trend was obtained with arginine supplementation.

4. Casein caused an increase in the concentration of serum insulin, but not glucagon. The glucagon level was increased proportionately with increasing amounts of arginine, while the addition of lysine showed no effect. The effects of added amino acids on serum insulin were inconclusive.

5. There was a parallel increase in serum apo $E$ and glucagon in response to arginine supplementation, while lysine supplementation increased serum apo $\mathbf{E}$.

6. Thus, arginine: lysine was more effective in regulating serum triglyceride than serum cholesterol. Insulin was associated with different effects of these proteins on serum lipids.
\end{abstract}

A number of human and animal studies have demonstrated that dietary protein is one of the principle determinants of plasma cholesterol levels and hence atherogenecity (Kritchevsky, 1979; Carroll, 1981). In most of these experiments, the effects of vegetable and animal protein have been compared; isolated soya-bean protein when replacing casein or other animal proteins reduces plasma cholesterol. It is reasonable to consider that the different effects on plasma cholesterol are attributed in part at least to the difference in the amino acid profiles of the proteins. However, not all the available evidence supports this concept (Hevia et al. 1980; Huff \& Carroll, 1980; Okita \& Sugano, 1981).

Kritchevsky and co-workers (Kritchevsky, 1979; Czarnecki \& Kritchevsky, 1980) have considered the arginine:lysine value which in soya-bean protein is twice that of casein $(1.07 v .0 .48)$. In rabbits, the addition of sufficient lysine to a soya-bean protein diet to lower the arginine:lysine value to 0.48 increased serum cholesterol and atherogenecity of the diet, but the effect of arginine supplementation of casein was not conclusive (Kritchevsky, 1979). In contrast, in a similar type of experiment with rats, we were unable to detect any effects of these manipulations (Nagata et al. 1981 a).

Since lysine has been shown to inhibit liver arginase (EC 3.5.3.I) activity (Cittadini $e t$ al. 1964), Kritchevsky (1979) hypothesized that in animals given casein more arginine might be available for incorporation into arginine-rich apoprotein (apo E) which is thought to be atherogenic (Shore \& Shore, 1974). In addition, arginine induces the release of glucagon (Eaton, $1973 a$ ) and the relative abundance of arginine in soya-bean protein may be relevant to the hypocholesterolaemic effect of that protein. Noseda \& Fragiacomo (1980)

\footnotetext{
- The preliminary part of the study was presented at the 12th International Congress of Nutrition, San Diego, August 1981.
} 
demonstrated that, when animal proteins were replaced with textured soya-bean protein, plasma levels of glucagon increased significantly while insulin remained apparently unchanged, thus glucagon:insulin was increased. The magnitude of the rise in plasma glucagon after infusion of arginine was also significantly greater after a soya-bean protein diet (Noseda et al. 1980). These observations suggest a possible contribution of hormonal status to the regulation of plasma cholesterol levels by dietary protein.

In the present experiments, the interaction between dietary protein, serum cholesterol level and hormonal status was studied in rats by widely altering arginine:lysine in soya-bean protein and casein diets.

\section{METHODS \\ Animals and diets}

Male Wistar rats (Kyudo Co., Kumamoto) weighing approximately $160 \mathrm{~g}$ were housed individually (Nagata et al. 1980, 1981 a). After feeding on experimental diets ad lib. for $40 \mathrm{~d}$, the diets were removed at 05.00 hours and blood was withdrawn from the abdominal aorta during 10.00-11.00 hours under light diethyl ether anaesthesia. The composition of the basal diet was the same with that reported previously (Nagata et al. 1980, 1981 a); a low-fat ( $10 \mathrm{~g}$ maize oil $/ \mathrm{kg}$ ) diet containing $200 \mathrm{~g}$ protein $/ \mathrm{kg}$ (soya-bean protein isolate or casein). Supplementation of L-arginine or L-lysine was achieved at the expense of the carbohydrate source, sucrose. In order to make the arginine : lysine value in protein sources identical, $8.6 \mathrm{~g}$ arginine or $17.2 \mathrm{~g}$ lysine $/ \mathrm{kg}$ were added to diets containing animal or plant proteins respectively (Nagata et al. 1981 a).

\section{Analytical procedures}

Blood serum was obtained by centrifugation. Serum- and liver-lipid components were analysed as described previously (Nagata et al. 1980, 1981 a). Serum glucose was measured by the $o$-toluidine-boric acid method (Glucose-Test Wako Kit, Wako Pure Chemicals, Osaka). Serum apolipoproteins A-I, B and E were determined by rocket immunoelectrophoresis according to Alaupovic et al. (1978) as modified by Imaizumi et al. (1982). Plasma glucagon ( $30 \mathrm{~K}$ antibody) and serum insulin were determined by radioimmunoassay at the clinical laboratories (Ohtsuka Assay Laboratories, Tokushima and Kitasato Biochemical Laboratories, Sagamihara for the first and second experiments respectively). The antisera used for insulin assay were from Dynapot (double antibody method, prepared from guinea pig and goat) in the first experiment and from Pharmacia (prepared from guinea pig) in the second experiment. The hepatic arginase activity was measured according to the method described by Schimke (1970).

\section{Statistical analyses}

Student's $t$ test (Fisher, 1970) and Scheffé's analysis of variance (Scheffé, 1959) were used to determine significance $(P<0.05)$ between two different protein groups and among four same-protein groups respectively for the results obtained in these experiments.

\section{RESULTS}

\section{Effects of addition of arginine to casein}

L-Arginine was added to the casein diet to raise the arginine:lysine value. Table 1 summarizes weight gain, food intake and liver weight of rats given these diets. There were no differences in weight gain and food intake between rats given casein and soya-bean protein. Addition of larger amounts of arginine to casein tended to increase food intake and weight gain slightly. Liver weight was to some extent heavier in rats given casein diets. 
Table 1. Body-weight gain, food intake and liver weight of rats given casein supplemented with arginine

(Mean values with their standard errors for six rats/dietary group)

\begin{tabular}{|c|c|c|c|c|c|c|c|}
\hline \multirow[b]{2}{*}{ Dietary regimen } & \multirow[b]{2}{*}{ Arginine:lysine } & \multicolumn{2}{|c|}{$\begin{array}{c}\text { Body-wt gain } \\
\text { (g) }\end{array}$} & \multicolumn{2}{|c|}{$\begin{array}{l}\text { Food intake } \\
\qquad(\mathrm{g} / \mathrm{d})\end{array}$} & \multicolumn{2}{|c|}{$\begin{array}{c}\text { Liver wt } \\
\text { (g/kg body-wt) }\end{array}$} \\
\hline & & Mean & $\mathrm{SE}$ & Mean & SE & Mean & SE \\
\hline Soya-bean protein & 1.07 & 196 & $8^{1 a}$ & $21 \cdot 9$ & $0.6^{1 \mathrm{a}}$ & $34 \cdot 3$ & $0.7^{1 a}$ \\
\hline Casein & 0.48 & 201 & $6^{1 \mathrm{~A}}$ & $20 \cdot 2$ & $0.4^{1 \mathrm{~A}}$ & $36 \cdot 1$ & $0.8^{1 \mathrm{~A}}$ \\
\hline Casein +1 Arg* & $1 \cdot 07$ & 218 & $9^{\mathrm{aA}}$ & $21 \cdot 9$ & $0.8^{\mathrm{aA}}$ & $36 \cdot 4$ & $1 \cdot 1^{\text {a A }}$ \\
\hline Casein + 2 Arg & 1.66 & 233 & $11^{\mathrm{A}}$ & $22 \cdot 8$ & $0.7^{\mathrm{A}}$ & $37 \cdot 3$ & $1 \cdot 2^{\mathrm{A}}$ \\
\hline Casein +5 Arg & 3.43 & 222 & $8^{\mathrm{A}}$ & 21.9 & $0 \cdot 5^{\mathrm{A}}$ & $33 \cdot 1$ & $1 \cdot 3^{\mathrm{A}}$ \\
\hline
\end{tabular}

Mean with a common numbered superscript between soya-bean protein and casein and mean with a common small-lettered superscript between groups at an equivalent arginine:lysine value were not significant: $P>0.05$. Mean with a common capital-lettered superscript among four casein groups was not significant: $P>0.05$.

* The amount of arginine added to make arginine:lysine equivalent to soya-bean protein is expressed as $1 \mathrm{Arg}$.

Serum levels of lipids and apolipoproteins are shown in Table 2. In agreement with the previous observations (Nagata et al. 1980, 1981 a), the concentration of serum cholesterol was significantly lower in rats given soya-bean protein than in the animals given casein. The increase in cholesterol was largely attributable to that of very low-density lipoprotein (VLDL)-cholesterol plus low-density lipoprotein (LDL)-cholesterol, since there was a relatively small difference in the concentration of high-density lipoprotein (HDL)-cholesterol $(399 \pm 28 \mathrm{mg} / 1$ for plant protein and $485 \pm 30 \mathrm{mg} / \mathrm{l}$ for animal protein). The addition of arginine at all levels in no way modified the hypercholesterolaemic effect of casein. The concentration of HDL-cholesterol was also unaltered by this manipulation (the mean value ranged from 461 to $539 \mathrm{mg} / \mathrm{l}$ ). Serum triglyceride levels were the same for rats given soya-bean protein and those given casein, an observation which was inconsistent with that of the previous experiment (Nagata et al. 1981a). The concentration of serum triglyceride was increased slightly when sufficient arginine was added to casein to make the arginine :lysine value the same as that of soya-bean protein, but it decreased gradually with larger amounts of arginine supplementation and became considerably lower at the highest arginine:lysine level. The concentration of serum phospholipid was consistently higher in all groups given casein.

The concentration of serum apo A-I was lower on feeding vegetable protein as compared with casein, and the difference was maintained even when arginine was added to casein. The serum level of apo B was apparently the same for the various dietary groups. Serum apo $\mathrm{E}$ level was significantly higher in rats given casein than in the animals given soya-bean protein and there was apparently a gradual dose-dependent increase in apo E in response to the addition of arginine.

As Table 3 shows, serum glucose levels were the same for all groups. The concentration of serum insulin was significantly higher when feeding casein, but the effect of arginine supplementation was not conclusive. Although rats given vegetable or animal protein had the same level of glucagon, arginine addition increased it progressively.

The concentration of liver cholesterol was significantly higher in rats given casein than in those given soya-bean protein (Table 4). The addition of arginine did not modify the cholesterol-increasing effect of casein. The hepatic triglyceride level also tended to increase on feeding casein and again arginine supplementation showed no effect. Neither the 


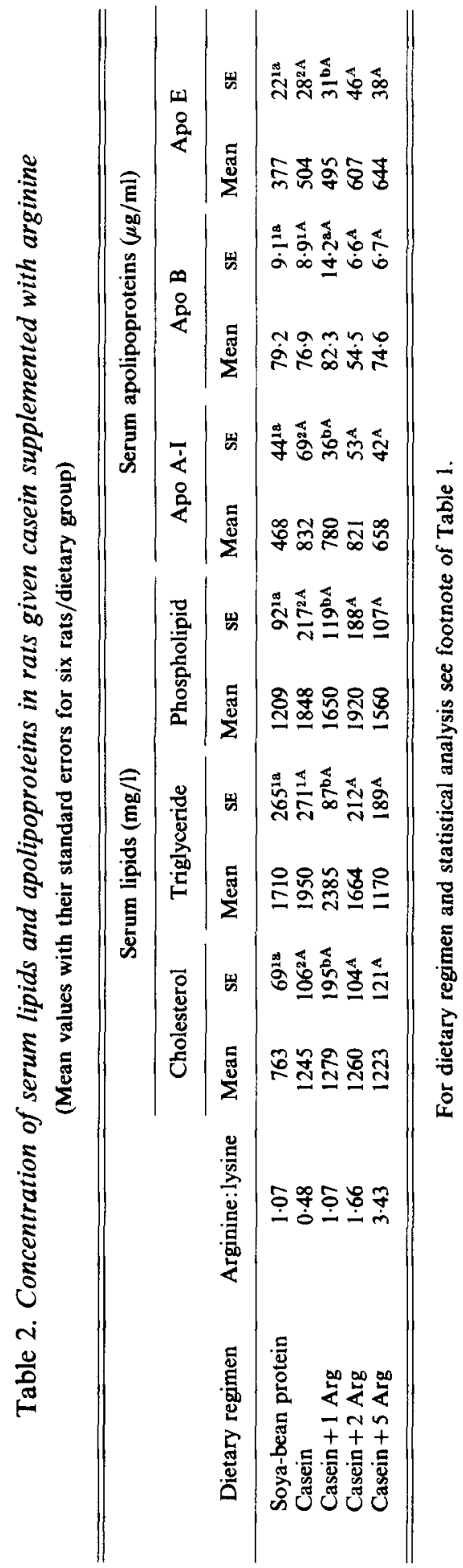


Table 3. Concentration of serum glucose, insulin and glucagon in rats given casein supplemented with arginine

(Mean values with their standard errors for six rats/dietary group)

\begin{tabular}{|c|c|c|c|c|c|c|c|}
\hline \multirow[b]{2}{*}{ Dietary regimen } & \multirow[b]{2}{*}{ Arginine:lysine } & \multicolumn{2}{|c|}{$\begin{array}{l}\text { Glucose } \\
(\mathrm{mg} / \mathrm{ml})\end{array}$} & \multicolumn{2}{|c|}{$\begin{array}{l}\text { Insulin } \\
(\mu \mathrm{U} / \mathrm{ml})\end{array}$} & \multicolumn{2}{|c|}{$\begin{array}{c}\text { Glucagon } \\
(\mathrm{pg} / \mathrm{ml})\end{array}$} \\
\hline & & Mean & SE & Mean & SE & Mean & SE \\
\hline Soya-bean protein & 1.07 & 1.86 & $0.07^{1 \mathrm{a}}$ & 113 & $15^{19}$ & 108 & $9^{1 \mathrm{a}}$ \\
\hline Casein & 0.48 & 1.82 & $0.04^{1 \mathrm{~A}}$ & 188 & $18^{2 \mathrm{~A}}$ & 112 & $8^{1 A}$ \\
\hline Casein + 1 Arg & $1 \cdot 07$ & 1.90 & $0.07^{\mathrm{aA}}$ & 218 & $39^{\mathrm{bA}}$ & 152 & $22^{\mathrm{aA}}$ \\
\hline Casein +2 Arg & 1.66 & 1.83 & $0.04^{A}$ & 249 & $32^{\mathrm{A}}$ & 146 & $12^{A}$ \\
\hline Casein + 5 Arg & 3.43 & $1 \cdot 81$ & $0.05^{A}$ & 161 & $27^{\mathrm{A}}$ & 167 & $14^{\mathrm{A}}$ \\
\hline
\end{tabular}

For dietary regimen and statistical analysis see footnote of Table 1.

Table 4. Concentration of lipid components and arginase activity in the liver of rats given casein supplemented with arginine

(Mean values with their standard errors for six rats/dietary group)

\begin{tabular}{|c|c|c|c|c|c|c|c|c|c|}
\hline \multirow[b]{3}{*}{ Dietary regimen } & \multirow{3}{*}{$\begin{array}{c}\text { Arginine: } \\
\text { lysine }\end{array}$} & \multicolumn{6}{|c|}{ Liver lipids (mg/g) } & \multirow{2}{*}{\multicolumn{2}{|c|}{$\begin{array}{l}\text { Arginase } \\
\text { activity* }\end{array}$}} \\
\hline & & \multicolumn{2}{|c|}{ Cholesterol } & \multicolumn{2}{|c|}{ Triglyceride } & \multicolumn{2}{|c|}{ Phospholipid } & & \\
\hline & & Mean & SE & Mean & SE & Mean & $\mathbf{S E}$ & Mean & SE \\
\hline Soya-bean protein & $1 \cdot 07$ & 1.98 & $0 \cdot 16^{1 a}$ & $15 \cdot 7$ & $0 \cdot 6^{1 \mathrm{a}}$ & $29 \cdot 0$ & $1 \cdot 7^{1 \mathrm{a}}$ & $94 \cdot 0$ & $17 \cdot 5^{1 \mathrm{a}}$ \\
\hline Casein & 0.48 & $2 \cdot 44$ & $0.07^{2 \mathrm{~A}}$ & $18 \cdot 0$ & $1 \cdot 3^{1 A}$ & $31 \cdot 4$ & $0.8^{1 \mathrm{~A}}$ & $95 \cdot 4$ & $14 \cdot 7^{1 \mathrm{~A}}$ \\
\hline Casein + 1 Arg & 1.07 & 2.63 & $0.08^{\mathrm{BA}}$ & $17 \cdot 8$ & $1 \cdot 5^{\mathrm{aA}}$ & $30 \cdot 8$ & $0.9^{\mathrm{aA}}$ & 104 & $14 \cdot 6^{\mathrm{aA}}$ \\
\hline Casein +2 Arg & 1.66 & $2 \cdot 38$ & $0.05^{\mathrm{A}}$ & $18 \cdot 1$ & $2 \cdot 4^{A}$ & $29 \cdot 6$ & $0.7^{\mathrm{A}}$ & 112 & $9 \cdot 2^{\mathrm{A}}$ \\
\hline Casein +5 Arg & 3.43 & 2.48 & $0.08^{\mathrm{A}}$ & $19 \cdot 6$ & $1 \cdot 3^{A}$ & $30 \cdot 9$ & $1 \cdot 0^{\mathrm{A}}$ & $75 \cdot 1$ & $8 \cdot 0^{\mathrm{A}}$ \\
\hline
\end{tabular}

* $\mu \mathrm{mol}$ Urea formed $/ \mathrm{mg}$ protein per $10 \mathrm{~min}$.

For dietary regimen and statistical analysis see footnote of Table 1.

difference in dietary protein nor the addition of arginine to casein influenced the activity of hepatic arginase.

\section{Effects of addition of lysine to soya-bean protein}

L-Lysine was added to the soya-bean protein diet to lower the arginine:lysine value. The experimental regimen for lysine addition was modified from that of the preceding trial in order to avoid the effect of dietary levels of the nitrogen source.

As Table 5 shows, the growth of rats was slightly lower on the soya-bean protein diet than on the casein diet. Lysine supplementation improved weight gain accompanying a slight increase in food intake. The liver weight was significantly lower in rats given soya-bean protein and lysine supplementation showed no effects.

Table 6 shows that concentrations of serum cholesterol, triglyceride and phospholipid were significantly lower when feeding soya-bean protein than casein. The addition of lysine to soya-bean protein did not influence to any extent the serum cholesterol level, but increased triglyceride and phospholipid to the level comparable with that of casein. The 
Table 5. Body-weight gain, food intake and liver weight of rats given soya-bean protein supplemented with lysine

(Mean values with their standard errors for six rats/dietary group)

\begin{tabular}{|c|c|c|c|c|c|c|c|}
\hline \multirow[b]{2}{*}{ Dietary regimen } & \multirow[b]{2}{*}{ Arginine:lysine } & \multicolumn{2}{|c|}{$\begin{array}{c}\text { Body-wt gain } \\
\text { (g) }\end{array}$} & \multicolumn{2}{|c|}{$\begin{array}{l}\text { Food intake } \\
\qquad(\mathrm{g} / \mathrm{d})\end{array}$} & \multicolumn{2}{|c|}{$\begin{array}{c}\text { Liver-wt } \\
\text { (g/kg body-wt) }\end{array}$} \\
\hline & & Mean & SE & Mean & SE & Mean & SE \\
\hline Casein & 0.48 & 223 & $10^{1 \mathrm{a}}$ & $20 \cdot 8$ & $0 \cdot 3^{12}$ & $36 \cdot 8$ & $1 \cdot 2^{1 a}$ \\
\hline Soya-bean protein & $1 \cdot 07$ & 190 & $5^{2 \mathrm{~A}}$ & $20 \cdot 8$ & $0 \cdot 3^{1 \mathrm{~A}}$ & $31 \cdot 9$ & $1 \cdot 0^{2 \mathrm{~A}}$ \\
\hline Soya-bean protein $+1 / 2$ Lys $*$ & 0.66 & 228 & $8^{A}$ & $23 \cdot 5$ & $0 \cdot 5^{\mathrm{A}}$ & 33.0 & $0.5^{\mathrm{A}}$ \\
\hline Soya-bean protein +1 Lys & 0.48 & 203 & $13^{\mathrm{aA}}$ & $22 \cdot 0$ & $0.9^{\mathrm{aA}}$ & $32 \cdot 5$ & $0.9^{\mathrm{bA}}$ \\
\hline Soya-bean protein +2 Lys & $0 \cdot 31$ & 232 & $10^{\mathrm{A}}$ & $23 \cdot 5$ & $0.8^{A}$ & $35 \cdot 3$ & $1 \cdot 7^{\mathrm{A}}$ \\
\hline
\end{tabular}

- The amount of lysine added to make arginine:lysine equivalent to casein is expressed as 1 Lys.

Mean with a common numbered superscript between casein and soya-bean protein and mean with a small-letterec superscript between groups at an equivalent arginine:lysine value were not significant: $P>0.05$. Mean with a commor capital-lettered superscript among four soya-bean protein groups was not significant: $P>0.05$.

concentration of serum HDL-cholesterol was also unaltered by this manipulation (the mean value ranged from 300 to $359 \mathrm{mg} / 1$, the corresponding value for rats given soya-bean protein alone was $340 \mathrm{mg} / \mathrm{l}$ ). Again, serum apo A-I was significantly lower with plant protein than with animal protein. The concentration of serum apo B was not influenced by the type of dietary protein and the effect of supplementary lysine was not consistent. The addition of lysine to soya-bean protein showed no effect on concentrations of serum apo A-I and apo B. Serum apo E concentration appeared lower in rats given soya-bean protein and it was similar to that of the casein group when lysine was added.

Neither dietary protein nor addition of lysine supplementation of soya-bean protein influenced serum glucose levels (Table 7). Again, the serum concentration of insulin, but not glucagon, was significantly higher in rats given casein than in those given soya-bean protein. One reason for the considerable difference in the absolute value of serum insulin between this and preceding trials is possibly the difference in the assay method by utilizing antisera prepared for human insulin assay. It has been found that,-when rat serum but not human serum was analysed for insulin by radioimmunoassay, the cross-reactivity varies depending on the source of the antisera. However, since the magnitude of the response to casein and soya-bean protein was similar in the two studies, the results can be evaluated for the purpose of comparison. The effect of the addition of lysine on the levels of these two hormones was variable, no consistent changes being observed in relation to the level of lysine added.

Effects of dietary proteins on liver lipids and the arginase activity are shown in Table 8. The concentration of liver cholesterol was again significantly lower when feeding soya-bean protein and it decreased gradually with increasing levels of lysine. The concentration of liver triglyceride was also lower in rats given plant protein, but addition of lysine showed no effect. The activity of hepatic arginase was the same between rats given soya-bean protein and casein, and it decreased only at the lower level of arginine:lysine. 


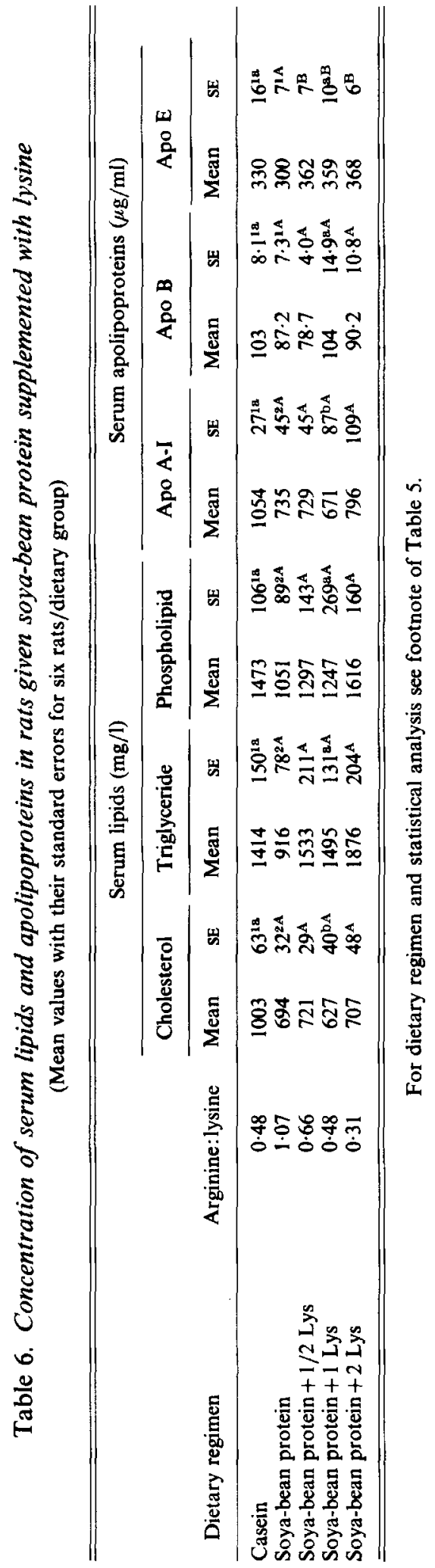


Table 7. Concentration of serum glucose, insulin and glucagon in rats given soya-bean protein supplemented with lysine

(Mean values with their standard errors for six rats/dietary group)

\begin{tabular}{|c|c|c|c|c|c|c|c|}
\hline \multirow[b]{2}{*}{ Dietary regimen } & \multirow[b]{2}{*}{ Arginine:lysine } & \multicolumn{2}{|c|}{$\begin{array}{l}\text { Glucose } \\
(\mathrm{mg} / \mathrm{ml})\end{array}$} & \multicolumn{2}{|c|}{$\begin{array}{l}\text { Insulin } \\
(\mu \mathrm{U} / \mathrm{ml})\end{array}$} & \multicolumn{2}{|c|}{$\begin{array}{l}\text { Glucagon } \\
\text { (pg/ml) }\end{array}$} \\
\hline & & Mean & $\mathbf{S E}$ & Mean & $\mathrm{SE}$ & Mean & $\mathrm{SE}$ \\
\hline Casein & 0.48 & 1.97 & $0.06^{12}$ & $62 \cdot 8$ & $2 \cdot 9^{1 \mathrm{~s}}$ & 101 & $9^{1 \mathbf{a}}$ \\
\hline Soya-bean protein & $1 \cdot 07$ & 1.83 & $0 \cdot 10^{1 \mathrm{~A}}$ & $46 \cdot 6$ & $2 \cdot 3^{2 \mathrm{~A}}$ & 113 & $14^{1 \mathrm{~A}}$ \\
\hline Soya-bean protein $+1 / 2$ Lys & 0.66 & $2 \cdot 01$ & $0 \cdot 14^{\mathrm{A}}$ & $70 \cdot 2$ & $5.9^{\mathrm{A}}$ & 154 & $20^{\mathrm{A}}$ \\
\hline Soya-bean protein +1 Lys & 0.48 & 1.81 & $0.08^{\mathrm{aA}}$ & $51 \cdot 8$ & $6 \cdot 0^{a A}$ & 107 & $8^{\mathrm{aA}}$ \\
\hline Soya-bean protein +2 Lys & $0 \cdot 31$ & 1.93 & $0.06^{\mathrm{A}}$ & 77.8 & $13 \cdot 7^{\mathrm{A}}$ & 122 & $10^{\mathrm{A}}$ \\
\hline
\end{tabular}

For dietary regimen and statistical analysis see footnote of Table 5.

\section{DISCUSSION}

The results of the present study show that arginine:lysine in soya-bean protein and casein seems to have little effect, if any, on serum cholesterol levels, although the concentration of liver cholesterol decreased when arginine: lysine was lowered by adding lysine to soya-bean protein. Thus the results are in conflict with observations made by Kritchevsky (1979), and essentially similar to those of Huff \& Carroll (1980) in rabbits, in which there was a low, negative correlation between arginine:lysine and plasma cholesterol. However, the rise of serum apo $\mathrm{E}$ on lowering arginine:lysine by adding lysine to soya-bean protein seems to correspond to the increased atherogenecity observed in rabbits (Kritchivsky, 1979). In contrast to serum cholesterol, the serum level of triglyceride was found to be more dependent on the arginine:lysine value; in general it was increased when arginine:lysine was reduced and reduced when the value was increased. Eklund \& Sjöblom (1980) revealed in female rats a significant negative correlation between dietary arginine content in various proteins and serum VLDL + LDL levels.

The elevation of serum cholesterol and triglyceride in rats given casein as compared with those given soya-bean protein may be related to the increase in serum insulin. Increased insulin secretion has been shown to produce increased hepatic triglyceride (Reaven et al. 1967) and cholesterol (Dugan et al. 1974) synthesis in rats. Serum levels of insulin were, however, not affected by changing the arginine:lysine value. Arginine supplementation of casein caused a dose-dependent increase in plasma glucagon with a concomitant decrease in serum triglyceride. This observation was consistent with a potent hypolipidaemic effect of glucagon by reducing hepatic synthesis and secretion of triglyceride-rich lipoproteins (Eaton, 1973b; Shade et al. 1979). There was, however, no such correlation between blood levels of glucagon and triglyceride when lysine was added to soya-bean protein.

The present values for serum apo B and apo E, but not apo A-I, differed from those of our previous studies (Nagata et al. $1981 \mathrm{a}$ ) in which serum apo B level was higher and apo E remained unchanged when feeding soya-bean protein, although there was a decreasing trend of these apolipoproteins when the amino acid mixture simulating soya-bean protein was fed. These discrepancies are presumably due to differences in feeding periods; $21 \mathrm{~d}$ and $40 \mathrm{~d}$ in the previous and present studies respectively. In rats given high-cholesterol diets for 10 weeks, concentrations of serum apo A-I and apo B were lower with soya-bean protein than with casein (Nagata et al. 1981 b). Arginine supplementation raised serum apo E levels, indicating that more arginine was available for incorporation into this apolipoprotein or 


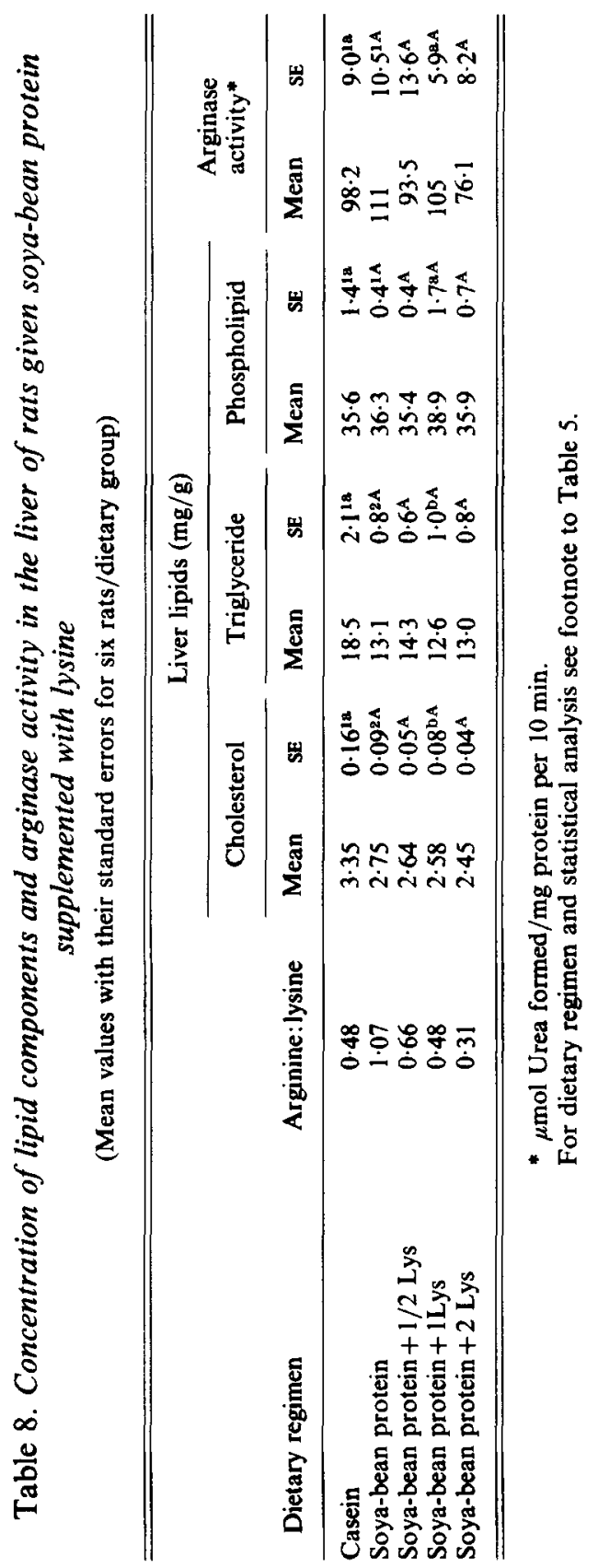


that arginine reduced the turnover of serum apo E. It was of interest to note that lysine supplementation of soya-bean protein also increased serum apo $\mathbf{E}$, although not in a dose-dependent manner. Lysine has been found to inhibit liver arginase activity (Cittadini et al. 1964) but this was not observed even when a large excess of lysine was added.

The extent of lipid peroxidation (mean $\pm \mathrm{SE}$ ) in serum as measured by the method of Yagi (1976), i.e. thiobarbituric acid-reactive substances, was consistently higher in rats given casein in comparison to those given soya-bean protein $(1.98 \pm 0.16$ v. $1.50 \pm 0.10 \mathrm{nmol} / \mathrm{ml}$ for the first experiment and $2 \cdot 14 \pm 0 \cdot 33 v \cdot 1 \cdot 39 \pm 0 \cdot 11 \mathrm{nmol} / \mathrm{ml}$ for the second experiment, both $P<0.05$ ). Neither the addition of arginine nor lysine influenced lipid peroxidation. It is thus possible that the difference in lipid peroxidation may be related to the observed changes in the concentrations of serum and liver lipids, since lipid peroxidation has been implicated as a possible cause of hypercholesterolaemia and atherosclerosis (Vlavdimirov et al. 1980).

The present study indicated that insulin, and possibly glucagon, are factors inducing dietary protein-dependent differences in serum lipids, although there was no definite relationship between arginine:lysine and serum levels of insulin or cholesterol. The responses to dietary protein differed from those observed in hypercholesterolaemic patients (Noseda \& Fragiacomo, 1980; Noseda et al. 1980). Since arginine is the most effective of the amino acids as a stimulus both for insulin (Fajans et al. 1968) and glucagon (Assan et al. 1977) secretion, it should be emphasized that our observations may reflect only one phase of the responses to arginine supplementation.

It is also unlikely that supplementary free amino acids behave similarly to those present as a peptide in the course of intestinal absorption and portal transport (Sleisenger \& Kim, 1979). In this respect, Eisenstein et al. (1979) reported that amino acids liberated during protein digestion function as glucagon secretagogues through some mechanism other than increased blood amino acid levels; protein intake was supposed to influence $\alpha$-cell function by stimulating release of gastrointestinal hormones. One approach to this problem is to utilize polypeptides of specific composition using the plastin reaction (Yamashita et al. 1971).

The circulating levels of these hormones are known to be significantly influenced by the feeding conditions (Fajans et al. 1968; Shade et al. 1979). Thus, in the present study we have chosen to set up a fixed feeding state; the diet was withdrawn at 05.00 hours and the blood sample was taken at 10.00-11.00 hours. This manipulation seemed to be appropriate for the evaluation of the effect of protein-type on serum levels of insulin and glucagon, if the process of intestinal protein digestion is primarily involved in the protein effect (Eisenstein et al. 1979). It is at present not clear whether the similar protein-dependent response could be duplicated even in a fasting state. More work is needed to elucidate the effect of protein type on these variables.

The authors thank Miss M. Koyanagi for the apolipoprotein assay and $\mathrm{Mr} \mathrm{K}$. Abe for technical assisstance. The soya-bean protein isolate was kindly provided by Fuji Oil Co., Osaka and amino acids by Ajinomoto Co., Tokyo. This study was supported by the Grant-in-Aid for Special Project Research (no. 412008) from the ministry of Education, Science and Culture.

\section{REFERENCES}

Alaupovic, P., Curry, M. D. \& McConathy, W. J. (1978). In International Conference of Atherosclerosis, p. 109 [L. A. Carlson, R. Paoletti, C. R. Sirtori and G. Weber, editors]. New York: Raven Press.

Assan, R., Attali, J. R., Ballerio, G., Boillot, J. \& Girard, A. J. (1977). Diabetes 26, 300.

Carroll, K. K. (1981). J. Am. Oil Chem. Soc. 58, 416.

Cittadini, D., Pietropalo, C., DeCristofaro, D. \& D'Ayjello-Caracciole, M. (1964). Nature, Lond. $203,643$. 
Czarnecki, S. \& Kritchevsky, D. (1980). J. Am. Oil Chem. Soc. 56, 388A.

Dugan, R. E., Ness, G. C., Lakshmann, M. R., Nepokroeff, C. M. \& Porter, J. W. (1974). Archs. Biochem. Biophys. 161, 499.

Eaton, R. (1973a). Metabolism. 22, 763.

Eaton, R. (1973b). J. Lipid Res. 14, 312.

Eisenstein, A. B., Strack, I., Gallo-Torres, H., Georgiadis, A. \& Miller, O. N. (1979). Am. J. Physiol. 236, E20.

Eklund, A. \& Sjöblom, L. (1980). J. Nutr., 110, 2321.

Fajans, S. S., Floyd, J. C. Jr., Knopf, R. F. \& Conn, J. W. (1968). Recent Progr. Hormone Res. $23,617$.

Fisher, R. A. (1970). Statistical Methods for Research Workers, 14th ed. p. 140. Edinburgh: Oliver \& Boyd.

Hevia, P., Frank, W. K., Edward, A. U. \& Visek, W. J. (1980). J. Nutr. 110, 1224.

Huff, M. W. \& Carroll, K. K. (1980). J. Nutr. 110, 1676.

Imaizumi, K., Murata, M. \& Sugano, M. (1982). J. Nutr. Sci. Vitam. 28, 281.

Kritchevsky, D. (1979). J. Am. Oil Chem. Soc. 56, 135.

Nagata, Y., Imaizumi, K. \& Sugano, M. (1980). Br. J. Nutr. 44, 113.

Nagata, Y., Tanaka, K. \& Sugano, M. (1981a). Br. J. Nutr. 45, 233.

Nagata, Y., Tanaka, K. \& Sugano, M. (1981 b). J. Nutr. Sci. Vitam. 27, 583.

Noseda, G. \& Fragiacomo, C. (1980). In Diet and Drugs in Atherosclerosis, p. 61 [G. Noseda, B. Lewis and R. Paoletti, editors]. New York: Raven Press.

Noseda, G., Fragiacomo, C., Descovich, G. C., Fumagalli, R., Bernini, F. \& Sirtori, C. R. (1980). In Drugs Affecting Lipid Metabolism, p. 355 [R. Fumagalli, D. Kritchevsky and R. Paoletti, editors]. Amsterdam: Elsevier/North-Holland Biomedical Press.

Okita, T. \& Sugano, M. (1981). J. Nutr. Sci. Vitam. 27, 379.

Reaven, G. M., Lemer, R. L., Stern, M. P. \& Farquhar, J. W. (1967). J. clin. Invest. 46, 1756.

Scheffé, H. (1959). The Analysis of Variance, p. 55. Lolidon: Wiley \& Sons.

Schimke, R. T. (1970). Meth. Enzym, 17A, 313.

Shade, D. S., Woodside, W. \& Eaton, R. P. (1979). Metabolism 28, 874.

Shore, B. \& Shore, V. (1974). Biochemistry 13, 1579.

Sleisenger, M. H. \& Kim, Y. S. (1979). New Engl. J. Med. 300, u59.

Vlavdimirov, Y. A., Olenew, V. I., Suslove, T. B. \& Cheremisina, Z. P. (1980). Adv. Lipid Res. $29,99$.

Yagi, K. (1976). Biochem. Med. 15, 212.

Yamashita, M., Arai, S., Tsai, S.-J. \& Fujimaki, M. (1971). J. Agr. Food Chem. 19, 1151. 